\title{
Neural Network Modeling the Potential of Steels WITH DIFFERENT CHROME CONTENT
}

\author{
Vadim Kramar, Veronika Dushko, Anna Rodkina, Vasiliy Alchakov \\ Federal State Educational Institution of Higher Education "Sevastopol State University”, \\ Universitetskaya st., 33, Sevastopol, 299053, Russian Federation
}

\begin{abstract}
The numerical predicting experiment the potential of steels with different chrome content with oxide film and without the oxide film are conducted using neural network modeling. Laboratory investigation results of steels St3, 09G2, 10CrSND, $20 \mathrm{Cr} 13$ and $12 \mathrm{Cr} 18 \mathrm{~N} 10 \mathrm{~T}$ on the installation for newformed surface creation are used for training the neural network. High performance neural network for predicting the steel potential with oxide film and the potential without the oxide film were determined for steels with different chrome content.
\end{abstract}

Keywords: steel potential; neural network; corrosion; marine vessel; chrome
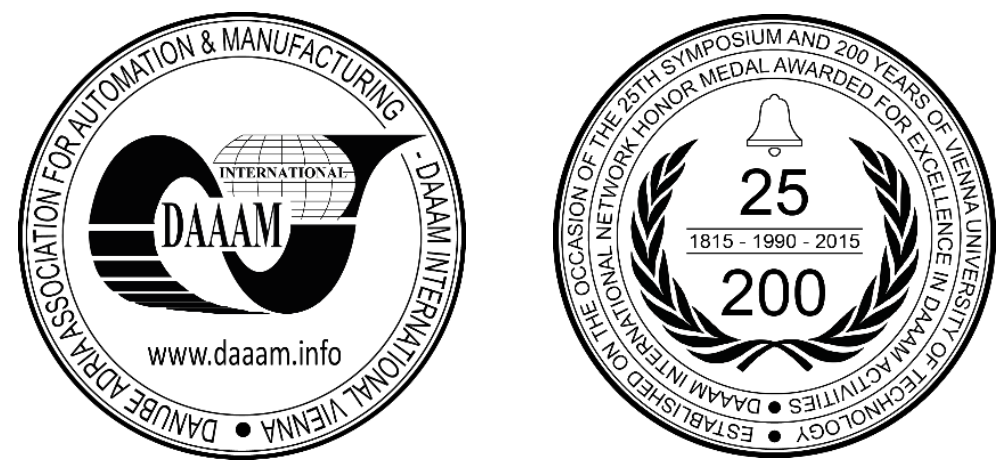

This Publication has to be referred as: Kramar, V[adim]; Dushko, V[eronika]; Rodkina, A[nna] \& Alchakov, V[asiliy] (2016). Neural Network Modeling the Potential of Steels with Different Chrome Content, Proceedings of the 26th DAAAM International Symposium, pp.0641-0647, B. Katalinic (Ed.), Published by DAAAM International, ISBN 9783-902734-07-5, ISSN 1726-9679, Vienna, Austria DOI: $10.2507 / 26$ th.daaam.proceedings.087 


\title{
1. Introduction
}

The problem of corrosion is not new, but its value continuously increased last decades, now in all production countries corrosion is one of the major problems. Acuteness of this problem increases as growth rate of corrosion losses exceeds growth rates of metal production. Corrosion leads to the substantial damages in all industrialized countries. The main corrosion losses are caused by premature metalwork failure which cost considerably exceeds the cost of the metal used on their manufacture. Costs of preventive maintenance, repair and replacement of separate details belong to this fact. The second largest item of losses is caused by exercise need of a complex actions for corrosion prevention $[1,2]$.

\author{
Nomenclature \\ $\mathrm{NaCl} \quad$ chloride of sodium \\ $\varphi \quad$ the electrochemical potential of metal, $\mathrm{mV}$ \\ $\mathrm{t}$ the period of experiment, $\mathrm{s}$ \\ St3 structural carbon steel \\ 09G2 structural alloy steel \\ 20Cr13 rust-resisting steel \\ 10CrSND structural low-alloyed steel \\ 12Cr18N10T structural cryogenic steel
}

Scientific and technical progress predetermined wide using of the high-strength steels with various kinds of technological influence, the high-loaded products and mechanisms. Their operation in ocean water often is followed by manifestation not only the equal corrosion, but also its local forms, including corrosion-mechanical destructions. When it became clear that many structural steels show the increased tendency to local corrosion, research of reliable local corrosion protection methods and means demanded to concentrate the main attention on identification the role of geometrical factors and systems electrochemical parameters, in particular, electrochemical potential of the corroding steel [3-5].

The cathodic protection system is recommended to install on the modern vessels and ocean engineering systems to protect from corrosion destructions. Thus it is necessary to provide corrosion protection and cracking of steel in local defects. Considering specifics of crack or any other local defect development, namely a newformed surface existence «inside» the crack, it is necessary to correct protective potential value for the purpose to ensure full protection of construction [6-7]. The surface layers play a special role in fatigue, as microcracks are formed on the free metal surface which is the course of destruction.

Earlier the opportunity to research metals without surface and oxide films are received, it was possible to study the metals behavior "inside" of the crack. The results show how much the steel potential value were critical "inside" the crack under corrosion-mechanical and fatigue destruction. The obtained results show that the electrochemical corrosion account is possible at application of high-tensile steels, which used in dynamically loaded constructions in corrosion environments. Here of also follows that steel polarization potential for a cathodic protection from local fractures is necessary to define on newformed surface.

The observed phenomenon immutability potential of the metal with a minimum of surface charge on the newformed surface has important theoretical and practical significance for electrochemical protection from corrosion and mechanical fracture of vessels and ocean engineering systems. Investigation of the steel protection parameters in relation to specific products and service conditions may allow to control the corrosion fatigue properties of metals and predict this characteristics in the future [8].

It is almost impossible to conduct the experimental researches of two potentials determination (with and without oxide film) for all kinds of steels. The best solution is the use of neural network modeling.

Computer simulation provides enough cheap and flexible environment for research and testing research ideas [9, 10]. Although the decision on the basis of neural network may look and behave like normal software, they are different in principle, since most implementations based on neural networks "learn" and not programmed: the network learns to perform the task, and is not programmed directly. The most neural networks are used when it is impossible to write a suitable program [9].

Neural network model operation is actively used for carrying out researches in various spheres of science, including in studying of corrosion processes, longevity of the corroding designs, and also at prediction of potential of steel at a cathodic protection [11]. In the papers [12-17] are described the concept of the neural networks

in studies of corrosion processes and durability of corrosive structures, and in predicting potential steel with cathodic protection. However, the aforesaid scientific experience does not consider the presence of the newformed and the surface does not take it into account in predicting neural network.

Thus, need of neural network model operation of potential of metal on a newformed surface is traced, for tutoring of a neural network results of the conducted laboratory researches will be used [8]. 


\section{Methods of the numerical experiment}

We pose the following purpose of the experiment: for predicting the steel potential with oxide film and the potential without the oxide film for various kinds of steel and salinity.

For this goal we use multifactor neural network structure shown in Fig.1. The input layer consists of eight neurons: salinity, \%; the carbon content in steel, \%; the manganese content in steel,\%; chromium content in steel, $\%$; silicium content in steel,\%; nickel content in steel,\%; the copper content in steel, \%; titanium content in steel, $\%$. The output layer comprises two neurons: potential steel oxide film $\mathrm{mV}$; potential-free steel oxide film $\mathrm{mV}$.

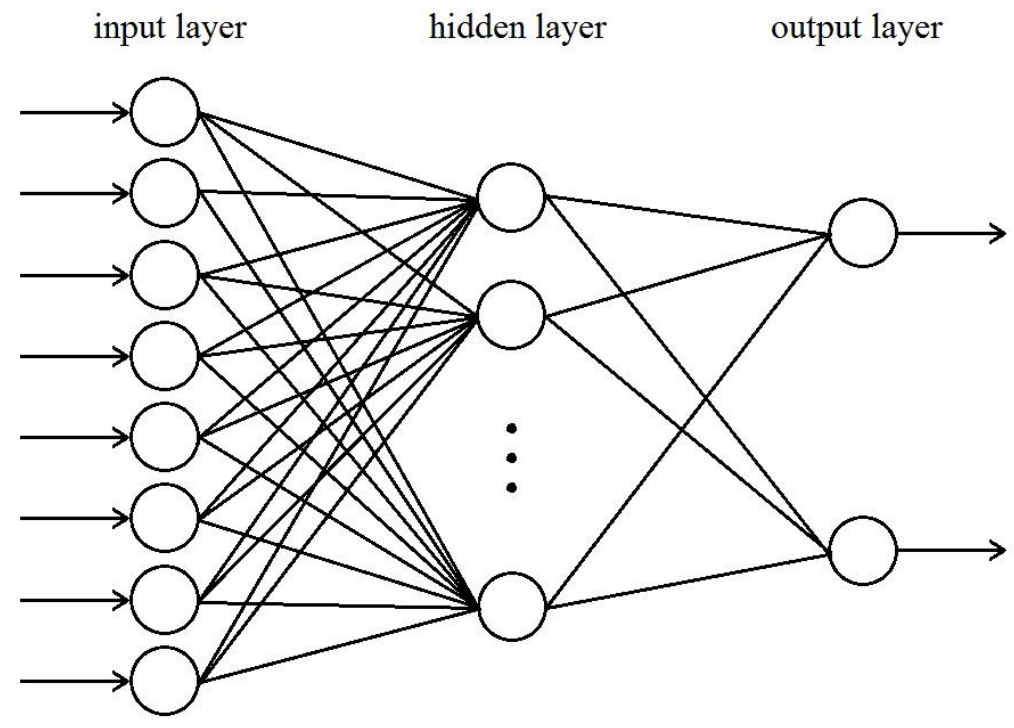

Fig. 1. Architecture of multifactor neural network

Numerical experiments were performed using the following types of neural networks: generalized regression neural network (GR NN), linear neural network, radial basis neural network with a minimal number of neurons (RB NN MMN), radial basis neural network with zero error (RB NN ZE).

For training the neural network are used the results of the laboratory tests carried out in the model solution of sea water of different salinity for steels St3, 09G2, 20Cr13, 10CrSND and 12Cr18N10T (Fig. 2) [8].

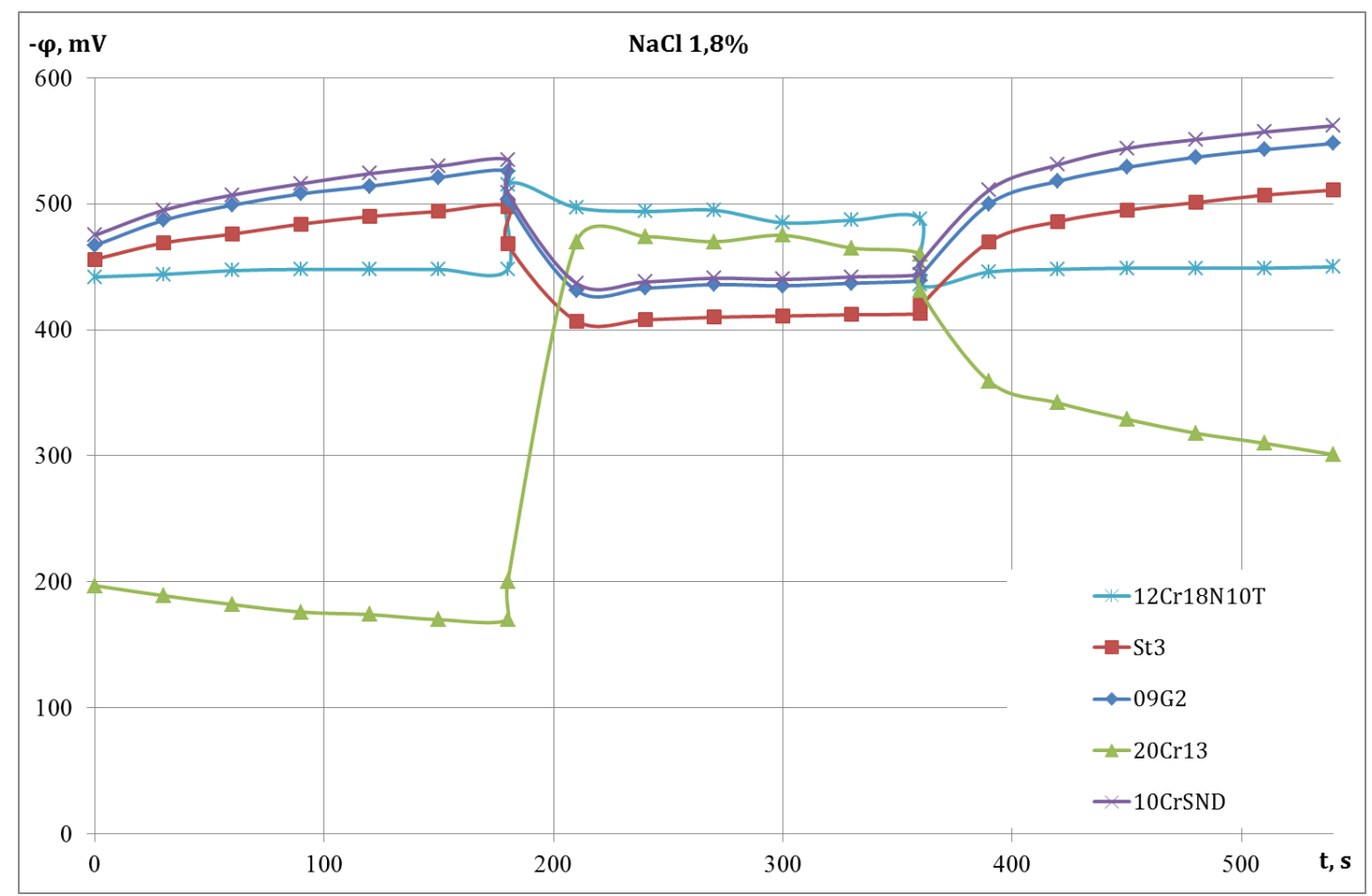




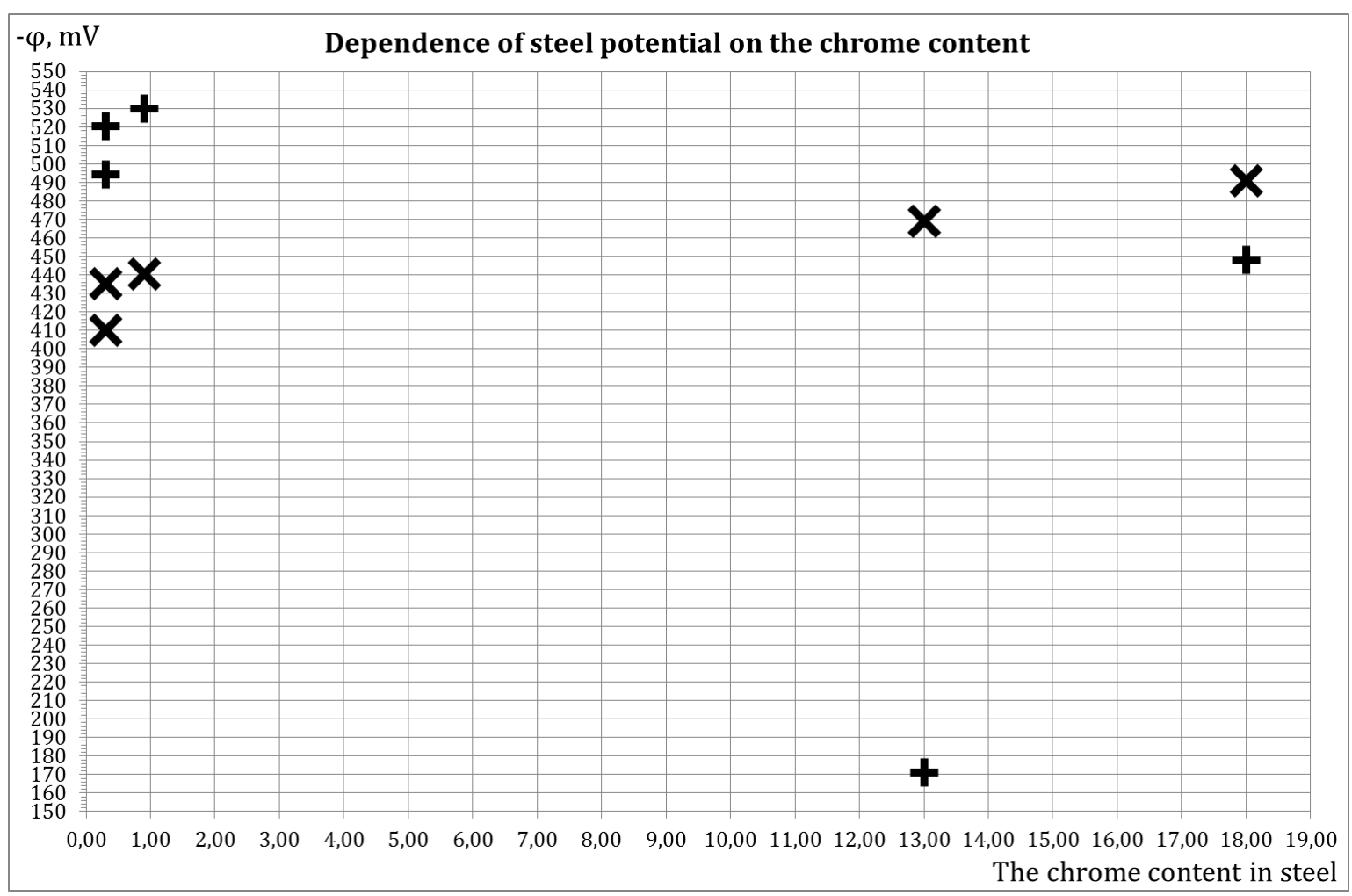

Fig. 2 Graphical representation potential gradient metals bars in $1.8 \%$ solution of $\mathrm{NaCl}$

\section{Results}

The results of numerical experiments show that more correctly work:

- generalized regression neural network with a deviation of 10,7 from 10 results are valid;

- linear neural network (7 from 10);

- radial basis neural network with the minimum number of neurons at $\mathrm{G}=$ newrb $(\mathrm{A}, \mathrm{Z}, 0.00)$ (6 from 10);

- radial basis neural network with zero error when $G=$ newrbe $(A, Z, 100)$ (6 from 10).

Visual representation of linear estimation of objectivity work neural network is shown in Fig. 3. Figure red line is divided into two areas. The lower region is characterized by the permissible relative error of the numerical experiment, which satisfies $70 \%$ of the results.

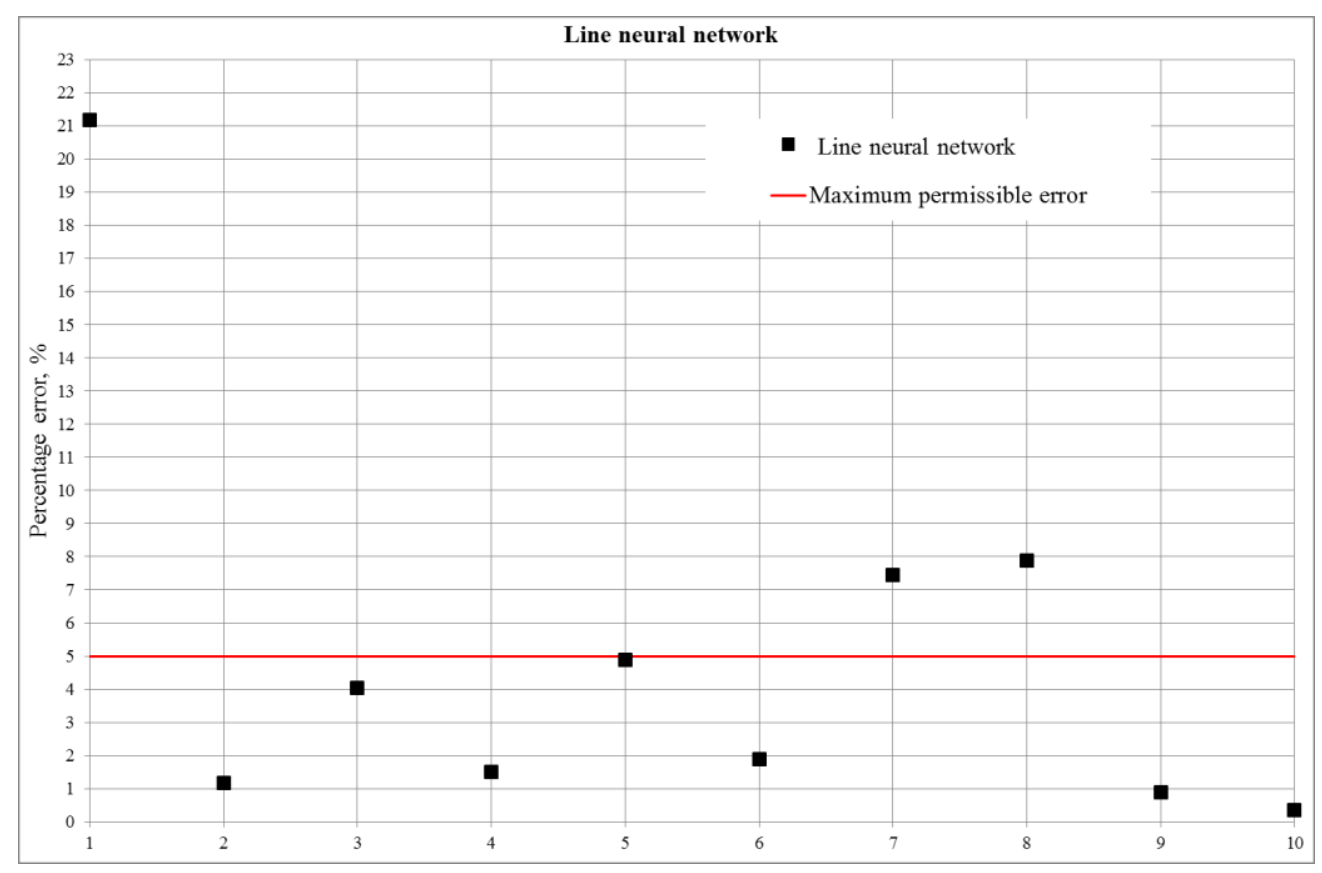

Fig. 3. The visual presentation of evaluation objectivity linear neural network operation: 
1 - the potential of $12 \mathrm{Cr} 18 \mathrm{~N} 10 \mathrm{~T}$ with the oxide film, $\mathrm{mV} ; 2$ - the potential of $12 \mathrm{Cr} 18 \mathrm{~N} 10 \mathrm{~T}$ without the oxide film, $\mathrm{mV}$;

3 - the potential of St 3 with the oxide film, $\mathrm{mV} ; 4$ - the potential of St 3 without the oxide film, $\mathrm{mV}$;

5 - the potential of $09 \mathrm{G} 2$ with the oxide film, $\mathrm{mV} ; 6$ - the potential of 09G2 without the oxide film, $\mathrm{mV}$;

7 - the potential of $20 \mathrm{Cr} 13$ with the oxide film, $\mathrm{mV} ; 8$ - the potential of $20 \mathrm{Cr} 13$ without the oxide film, $\mathrm{mV}$;

9 - the potential of $10 \mathrm{CrSND}$ with the oxide film, $\mathrm{mV} ; 10$ - the potential of $10 \mathrm{CrSND}$ without the oxide film, $\mathrm{mV}$.

The relative error is beyond the maximum permissible errors in forecasting steels potential.

In order to improve the quality of forecasting potential rust-resisting steels, it is decided to conduct further research, by splitting two training sample:

1. steels without chrome $-\mathrm{St} 3,09 \mathrm{G} 2$;

2. chrome steels $-20 \mathrm{Cr} 13,10 \mathrm{CrSND}$ и $12 \mathrm{Cr} 18 \mathrm{~N} 10 \mathrm{~T}$.

The results predicting the potential for steels without chrome are shown in Fig. 4, demonstrate the following:

- generalized regression neural network with a deviation of 10, 6 from 6 results are valid;

- linear neural network (6 from 6);

- radial basis neural network with the minimum number of neurons at $\mathrm{G}=$ newrb(A, $\mathrm{Z}, 0.00)$ (6 from 6);

- radial basis neural network with zero error at $\mathrm{G}=$ newrbe $(\mathrm{A}, \mathrm{Z}, 100)$ (5 from 6 , and the unsatisfactory result goes beyond a tolerance limit slightly).

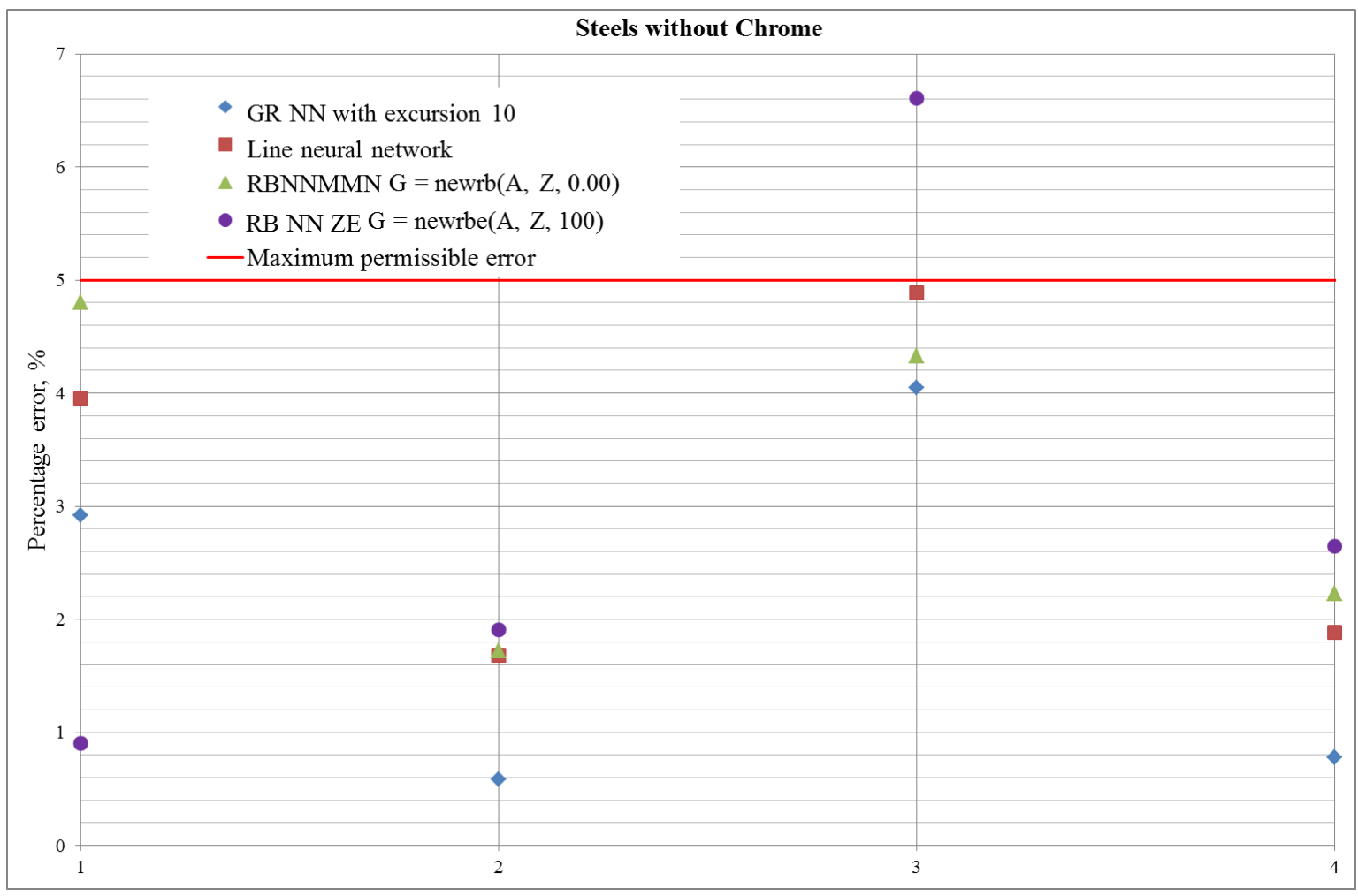

Fig. 4. The visual presentation of evaluation objectivity works of different kinds of neural networks for steels without chrome:

1 - the potential of $\mathrm{St} 3$ with the oxide film, $\mathrm{mV} ; 2$ - the potential of $\mathrm{St} 3$ without the oxide film, $\mathrm{mV}$;

3 - the potential of $09 \mathrm{G} 2$ with the oxide film, $\mathrm{mV} ; 4$ - the potential of $09 \mathrm{G} 2$ without the oxide film, $\mathrm{mV}$.

The results predicting the potential for chrome steels are shown in Fig. 5, demonstrate the following best combination of steel types and neural networks types:

- for steel 12Cr18N10T acceptable results provides generalized regression neural network with a deviation of 10;

- for steel $20 \mathrm{Cr} 13$ acceptable results provides radial basis neural network with the minimum number of neurons

- $\quad$ at $\mathrm{G}=$ newrb(A, $\mathrm{Z}, 0.00)$;

- for steel $10 \mathrm{CrSND}$ acceptable results provide radial basis neural network with zero error at $\mathrm{G}=$ newrbe $(\mathrm{A}, \mathrm{Z}$, 100) and linear neural network. 


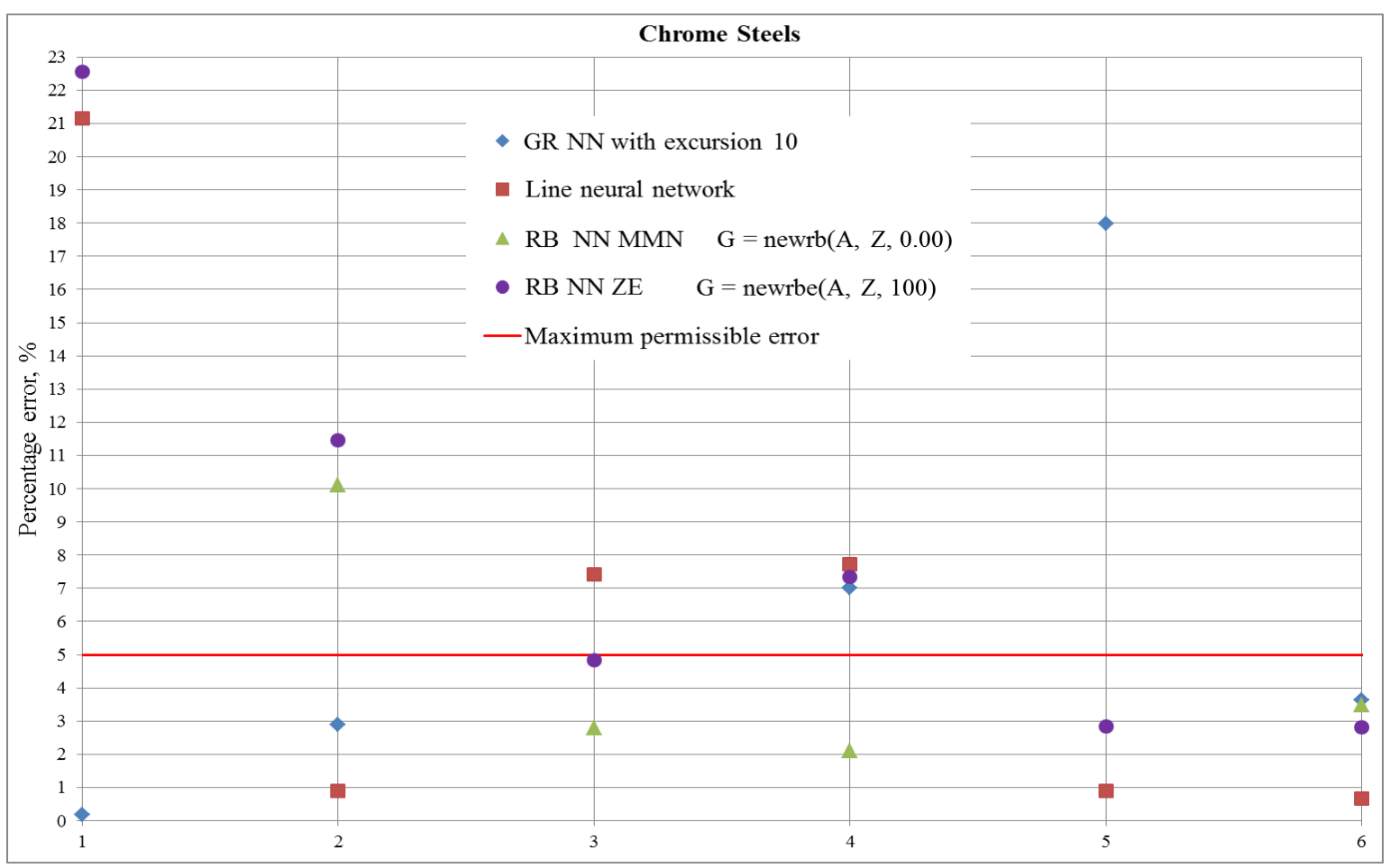

Fig. 5. The visual presentation of evaluation objectivity works of different kinds of neural networks for chrome steels: 1 - the potential of $12 \mathrm{Cr} 18 \mathrm{~N} 10 \mathrm{~T}$ with the oxide film, $\mathrm{mV} ; 2$ - the potential of $12 \mathrm{Cr} 18 \mathrm{~N} 10 \mathrm{~T}$ without the oxide film, $\mathrm{mV}$;

3 - the potential of $20 \mathrm{Cr} 13$ with the oxide film, $\mathrm{mV} ; 4$ - the potential of $20 \mathrm{Cr} 13$ without the oxide film, $\mathrm{mV}$;

5 - the potential of $10 \mathrm{CrSND}$ with the oxide film, $\mathrm{mV} ; 6$ - the potential of $10 \mathrm{CrSND}$ without the oxide film, $\mathrm{mV}$.

\section{Conclusion}

Using several types of neural networks we performed the numerical experiment of the potential prediction of steel with an oxide film and the potential of steel without the oxide film for various kinds of steel and salinity of sea water. The most effective for tasks neural network on the basis of permissible relative error of the numerical experiment was identified, which satisfies $70 \%$ of the results.

The following stage executed improvement of quality of prediction of potentials, by means of division of the training selection based on the quantitative content of chrome in steel. Generalized regression neural network with a deviation of 10 , linear neural network, radial basis neural network with the minimum number of neurons provide the highest precision of prediction of potentials for carbon and low-alloyed steels $-100 \%$ results do not go beyond a maximal and admissible percentage error. However and radial basis neural network with zero error provides adequate accuracy, and the unsatisfactory result goes beyond a tolerance limit slightly.

Chrome bearing steels it is recommended to apply to ensuring the highest precision of prediction of potential:

- radial basis neural network with zero error or linear neural network for low-alloyed steels with the content of chrome less $5 \%$;

- radial basis neural network with the minimum number of neurons for steels with the content of chrome $5 \ldots 15$ $\%$;

- generalized regression neural network for high-alloyed steels with the content of chrome more $15 \%$.

Thus, a predict model the potential of steel oxide film and steel building without oxide film for various kinds of steels and salinity of sea water was developed, which avoids costly and time consuming experimental studies.

Based on the above, the quality of the vessels and ocean engineering systems cathodic protection from corrosionmechanical destruction is improved and the spread of local destruction is prevented, based on the precise choice of protective potential, taking into account the newformed surface.

\section{References}

[1] Ozhiganov J.G., Rodkina A.V., Ogorodova A.A. Corrosion-mechanical destruction problem and danger of marine constructions catastrophes at these destructions. - Environmental Management Systems. Issue 15. - Sevastopol, 2011. - pp. 288-295. Ozhiganov Yu.G. Problema korrozionno-mekhanicheskih razrushenij i opasnost' katastrof morskih sooruzhenij pri etih razrusheniyah / Yu.G. Ozhiganov, A.V. Rod'kina, A.A. Ogorodova // Sistemy kontrolya okruzhayushchej sredy. Vypusk 15. - Sevastopol', 2011 g. - S. 288-295.

[2] Johnson J. Cost of corrosion in ships, report. Dublin, Ohio: CC Technologies Laboratories, Inc.; 2001. 
[3] Ozhiganov J.G., Rodkina A.V. Corrosion cracking preventing of shipbuilding steels on vessels and installations. Sevastopol, 2009.

pp. 118-125.

Ozhi ganov Yu.G. Predotvrashchenie korrozionnogo rastreskivaniya sudostroitel'nyh stalej na morskih sudah i sooruzheniyah / YU.G. Ozhiganov, A.V. Rod'kina // Sovershenstvovanie proektirovaniya i ekspluatacii morskih sudov i sooruzhenij: materialy IV Vseukrainskoj studencheskoj nauch.-tekhn. konf., 2-5 dekabrya 2009 g. Sevastopol': Izd-vo SevNTU, 2009. - S. 118-125.

[4] Henrik Wall, Lars Wadsö, Corrosion rate measurements in steel sheet pile walls in a marine environment, Marine Structures №33, 2013.

pp. 21-32.

[5] Rahman Seifi, Naser Omidvar, Fatigue crack growth under mixed mode I + III loading, Marine Structures №34, 2013. pp. 1-15.

[6] Ozhiganov Yu.G., Rodkina A.V., Azarenko E.V., Ogorodova A.A. Existent and Perspective Corrosive-Mechanical Protection Systems from Underwater Surface Destructions of Marine Vessels and Constractions. Proceedings of Sevastopol National University of Nuclear Energy and Industry. Sevastopol, 2011. - Issue 4(40). - pp. $146-153$.

Ozhiganov Yu.G. Sushchestvuyushchie i perspektivnye sistemy zashchity ot korrozionno-mekhanicheskih razrushenij podvodnoj poverhnosti morskih sudov i sooruzhenij / Yu.G. Ozhiganov, A.V. Rod'kina, E.V. Azarenko, A.A. Ogorodova // Zbirnik naukovih prac' Sevastopol's'kogo nacional'nogo universitetu yadernoï energiï ta promislovosti, 2011. - Vip. 4(40). - S.146-153.

[7] Ozhiganov J.G., Rodkina A.V., Ogorodova A.A., Kalinina O.I. Cathodic Polarization at Uncharged Surface Potential as the Way of Protection from Corrosive-Mechanical Destruction in Sea Water. Scientific Bulletin of Kherson State Maritime Institute. Kherson, 2011. - Issue 2(5). - pp. 140-148.

Ozhiganov Yu.G. Katodnaya polyarizaciya pri potenciale nezaryazhennoj poverhnosti kak sposob zashchity sudokorpusnyh konstrukcij ot korrozionno-mekhanicheskih razrushenij / Yu.G. Ozhiganov, A.V. Rod'kina, A.A. Ogorodova, O.I. Kalinina // Naukovij visnik Hersons'kogo derzhavnogo mors'kogo institutu, 2011. - Vip. 2(5). S.140-148.

[8] Kramar Vadim, Influence of Stress-Corrosion Fractures on Potential of Ship-Building Metals in the Sea Water / Vadim Kramar, Veronika Dushko, Anna Rodkina, Anastasiia Zaiets // Annals of DAAAM for 2014, Volume 25, No.1, ISSN 2304-1382 \& Proceedings of the 25th DAAAM International Symposium on Intelligent Manufacturing and Automation, Volume 100, ISSN 1877-7058, Edited by Branko Katalinic, ELSEVIER, 2015. - P. 1068-1074.

[9] Kallan R. The basic concepts of neural networks. - Moscow, 2001. - 287 p.

Kallan R. Osnovnye koncepcii nejronnyh setej. : Per. s angl. - M.: Izdatel'skij dom «Vil'yams», 2001. - 287 s.

[10] Zhilenkov Anton, Investigation Performance of Marine Equipment with Specialized Information Technology / Anton Zhilenkov, Sergei Chernyi // Annals of DAAAM for 2014, Volume 25, No.1, ISSN 2304-1382 \& Proceedings of the 25th DAAAM International Symposium on Intelligent Manufacturing and Automation, Volume 100, ISSN 1877-7058, Edited by Branko Katalinic, ELSEVIER, 2015. - P. 1247-1252.

[11] Kramar Vadim, Steel potential predicting using the neural network / Vadim Kramar, Anna Rodkina, Veronika Dushko // Proceedings of the Symposium Automated Systems and Technologies AST'2015 Edited by Prof. Viacheslav P. Shkodyrev and Prof. Ludger Overmeyer St. Petersburg, Russia, 25-26 May 2015. - P. $215-221$.

[12] Hussein Kadhim Mohammed AL-Shareefi. Neural Network Corrosion Control by Impressed Cathodic Protiction / University of Technology - Baghdad - Iraq. 2009.

[13] Gorbatkov S.A., Beskhlebnova G.A. The technology of neural network modeling of pipelines corrosion processes. - Ufa branch of the All-Russian Correspondence Financial and Economic Institute.

Gorbatkov S.A., Beskhlebnova G.A. Tekhnologiya nejrosetevogo modelirovaniya korrozionnyh processov magistral'nyh truboprovodov // Ufimskij filial vserossijskogo zaochnogo finansovo-ekonomicheskogo instituta. mailto: gorbatkov.ufa@vzfei.ru

[14] Murav'ev K.A. Neural network analysis of welded joints fracture toughness parameters of structural steels. - New University. A series of "Engineering". №1(7). 2012. pp. 42-48.

Murav'ev K.A. Nejrosetevoj analiz pokazatelej treshchinostojkosti svarnyh soedinenij konstrukcionnyh stalej // Novyj universitet. Seriya «Tekhnicheskie nauki». №1(7). 2012. S. 42-48.

[15] Chernyi S. The implementation of technology of multi-user client-server applications for systems of decision making support / Metallurgical and Mining Industry. 2015. Vol. 3. pp. 60- 65.

[16] Zelencov D.G., Gavrilyuk Yu.V., Novikova L.V. Using neural networks for solving life calculation corrosive structures. - Eastern-European Journal of Enterprise Technologies. №5/1 (65). - 2013. - pp. 71-74.

Zelencov D.G., Gavrilyuk Yu.V., Novikova L.V. Ispol'zovanie nejronnyh setej pri reshenii zadach rascheta dolgovechnosti korrodiruyushchih konstrukcij. // Vostochno-Evropejskij zhurnal peredovyh tekhnologij. №5/1 (65). $-2013 .-$ S. 71-74.

[17] Zelencov D.G., Radul' A.A. Solution of the durability of structures under corrosive restriction on the allowable error. - Metal constructions. Tom 17. №1. - 2011. - pp. 25-32.

Zelencov D.G., Radul' A.A. Reshenie zadachi dolgovechnosti korrodiruyushchih konstrukcij pri ogranichenii na dopustimuyu pogreshnost'. //Metallicheskie konstrukcii. Tom 17. №1. - 2011. - S. 25-32. 